\title{
Approach Phytochemistry of Secondary Metabolites of Maytenus guia- nensis Klotzsch Ex Reissek (Celastraceae)
}

\author{
Abordagem Fitoquímica de Metabólitos Secundários em Maytenus guianensis \\ Klotzsch Ex Reissek (Celastraceae)
}

Renato Abreu Lima ${ }^{1,4}$, Fernanda Bay-Hurtado ${ }^{2,4}$, Dionatas Ulises de Oliveira Meneguetti $i^{3,4}$,
João Bezerra Facundo ${ }^{4}$, Júlio Sancho Linhares Teixeira Militão e Valdir Alves Facundo,

${ }^{1}$ Programa de Pós-Graduação em Biodiversidade e Biotecnologia, Universidade Federal do Amazonas, - Porto Velho, RO renatoabreu07@hotmail.com

${ }^{2}$ Pesquisadora, UNIR, Departamento de Zootecnia, Câmpus de Presidente Médici, RO

fernandabay@unir.br

${ }^{3}$ Colégio de Aplicação e Laboratório de Fisiofarmacologia da Universidade Federal do Acre, Rio Branco, Acre, Brasil

${ }^{4}$ Laboratório de Pesquisa em Química de Produtos Naturais, Universidade Federal de Rondônia, Porto Velho, RO

\begin{abstract}
The Brazilian Amazon rainforest, even for its richness and biological diversity, can offer the opportunity for innovative and efficient discovery of molecules with potential use in large scale. The interest in secondary metabolites have grown tremendously in recent years due to its wide use as raw material in the preparation of substances with biological activity. Specifically in relation to plants producing amazonian essential oils and plant extracts, the Maytenus guianensis is a shrub native to our region, being popularly known as fruit-Werewolf. The leaves are used as anti-inflammatory and infections is also indicated in the treatment of arthritis and hemorrhoids. Thus, the present study aimed to identify the classes of secondary metabolites from the ethanol extract of the leaves, stems and bark of M. guianensis. We carried out the identification of secondary metabolites with plant extract using specific reagents alkaloids, glycosides cardiotonic, coumarins, flavonoids, tannins, saponins and triterpenes, based on coloration and precipitation. It was found that all the studied structures show botanical alkaloids, coumarins, flavonoids and tannins using any specific reagents. However, the absence of a secondary metabolite cardiotonic glycoside was found in most of the tested reagents. The results of this study revealed that this species has secondary metabolites which can serve as raw material for synthesis of bioactive substances, particularly drugs and are used in many preparations to benefit human health, such as in the production of food and biological activity against microorganisms.
\end{abstract}

Keywords: Maytenus; Celastraceae; Triterpenes.

\section{Resumo}

A Floresta Amazônica Brasileira, devido sua riqueza e diversidade biológica, pode oferecer a oportunidade para descobertas de inovadoras e eficientes moléculas com potencial de uso, em larga escala. O interesse em metabólitos secundários tem crescido muito nos últimos anos, devido à sua ampla utilização como matéria-prima na preparação de produtos ou formulações com atividade biológica, especificamente em relação às plantas amazônicas produtoras de óleos essenciais e extratos vegetais. Maytenus guianensis é uma árvore nativa da região Norte, sendo conhecido popularmente como chichuá. Suas folhas são utilizadas como anti-inflamatório, no tratamento de infecções, artrite e hemorroidas. Com isso, o presente trabalho teve como objetivo identificar as classes de metabólitos secundários do extrato etanólico dos talos, folhas e cascas de M. guianensis. Realizouse a identificação de metabólitos secundários com o extrato da planta utilizando reagentes específicos de alcaloides, glicosídeos cardiotônicos, cumarinas, flavonoides, taninos, saponinas e triterpenos, reações de precipitação e coloração. Verificou-se que todas as estruturas botânicas estudadas apresentaram alcaloides, cumarinas, flavonoides e taninos utilizando todos os reagentes específicos. Porém, a ausência do metabólito secundário glicosídeo cardiotônico foi verificado na maioria dos reagentes testados. Os resultados obtidos neste estudo revelaram que a espécie estudada apresenta metabólitos secundários que podem servir como matéria-prima para a síntese de substâncias bioativas, especialmente fármacos, além de serem utilizados em diversos preparos para benefício na saúde humana, como na produção de alimentos e na atividade biológica contra microrganismos.

Palavras-chave: Maytenus; Celastraceae; Triterpenos.

Recebido: 27/04/2016 Aceito: 10/06/2016 


\section{Introduction}

The Brazil is recognized as one of the most expressive biodiversity of the biosphere and plays a very important role in human welfare and health, by providing basic goods and ecosystem services. With over 55,000 described species, which corresponds to $22 \%$ of the world total, this rich biodiversity is known for harboring many species of plants, used over time in medicine, and it is directly related to the associated traditional knowledge. Approximately $48 \%$ of the drugs used in therapy arise, directly or indirectly, from natural products, especially medicinal plants (ALHO, 2012).

Natural products with antimicrobial activity, from plant or microbial, have a prominent importance in bioprospecting research since the antibiotics available in the market are increasingly ineffective due to the emergence of resistant strains, which has become a global concern (ANDRADE, 2009). Thus, several studies have been conducted aiming the use of natural products as a source of active substances against pathogenic bacteria (DAS et al., 2007; ZILBERG et al., 2004).

The Amazon forest stands out with the highest floristic diversity of the world, but there are few studies on its chemical and pharmacological potential. Thus, this forest has several plant and microbial species that may contain non-described secondary metabolites or therapeutic potential that was not studied yet, and that could be used against various diseases, especially regarding diseases caused by bacterial agents (TANAKA et al., 2005).

The Celastraceae family comprises about 98 genera and about 1,264 species and it may be found throughout Brazil (OLIVEIRA et al., 2006; FONSECA et al., 2007). There are several studies that demonstrate that the principles of the biological interest are associated with flavonoids, sesquiterpenes, alkaloids, and pentacyclic triterpenes (GONÇALVES et al., 2005; MICHELIN et al., 2005; OLIVEIRA et al., 2006).

Maytenus guianensis is a small size tree endemic of solid ground in the Amazon; this plant is known as chichuá, xixuá, chuchahuasi, chucchu huashu, chuchuasi, chuchasha and tonipulmon (DUKE; VÁSQUEZ, 1994; REVILLA, 2002).

Its roots and stems are also used as an analgesic, anti-inflammatory, aphrodisiac, muscle relaxant, anti -rheumatic and anti-diarrheal. The tea and ointment, made from the leaves of the species, are also indicated for the treatment of arthritis, sexual impotence, colds, bronchitis, hemorrhoids, worm infections, lumbago, external ulcers, and gynecological purposes (BORRAS, 2003). As a cosmetic it is used in skin rashes and to prevent the skin cancer (REVILLA, 2002), furthermore, it has antiparasitic action (MACARI; PORTELA; POHLIT, 2006), demonstrating a great ethnopharmacological potential to be explored.

Therefore, this study aimed to identify the secondary metabolites of botanical structures (leaves, bark and stems) of ethanol extracts of M. guianensis.

\section{Method}

\section{Plant collection}

The phytochemical study of the M. guianensis (leaves, bark and stems) was carried out at the Research Laboratory of Chemistry of Natural Products (LPQPN) of the Federal University of Rondônia (UNIR) in Porto Velho, Rondônia State, Brazil. The collection of the fresh bark of M. guianensis was conducted in the Adolpho Ducke Forest Reserve, located at the $\mathrm{km} 26$ in the highway Manaus-Itacoatiara (AM-010), Manaus, Amazonas State, at the geographic coordinates $0^{\circ} 10^{\prime} \mathrm{S}, 67^{\circ} 05^{\prime} \mathrm{W}$, in 2010 summer season. The botanical identification was performed by sending a voucher specimen to the Herbarium of the National Institute for Amazonian Research (INPA), where it was registered under the number 188,485 and identified by the researcher Dr. José Eduardo da Silva Ribeiro.

\section{Phytochemical study}

The leaves, bark and stems were adequately dried in an electric oven with air circulation at a temperature of $50{ }^{\circ} \mathrm{C}$ for 48 hours. Subsequently, they were ground to further increase the contact surface, then, the obtained material was subjected to three extractions by percolation with $95 \%$ ethanol (P.A.) at room temperature for three days, each. After the ethanol evaporation, we obtained the ethanolic extract called MGCE. Phytochemical tests were performed with the ethanol extract, based on precipitation and coloration of the extracts diluted in specific solution and reagents for each test as Matos (2009):

Alkaloids

To perform the assay we used $2.0 \mathrm{~mL}$ of the ethanolic solution is added $2.0 \mathrm{~mL}$ of hydrochloric acid (10\%), which heated the mixture for 10 minutes. After cooling, the extract was divided into three test tubes and placed in eight drops using Pasteur pipette, the reagents following recognition:

Tube 1 - Reactive Mayer: watching white precipitate formation or light white haze;

Tube 2 - Reactive Dragendorff: watching precipitate formation of orange color red;

Tube 3 - Reactive Wagner: observing orange color precipitate formation.

Glycosides cardiotonic

A $2.0 \mathrm{~mL}$ solution of the extract was added $3.0 \mathrm{~mL}$ of lead acetate solution $10 \%$ and $2.0 \mathrm{~mL}$ of distilled water. Heated the mixture in a water bath for 10 minutes. Then the extract was filtered and stirred with $10.0 \mathrm{~mL}$ of chloroform, the chloroform phase separated in 4 test tubes. After evaporation of chloroform, the formation of 
residues in the tubes, which were added the following reagents:

Tube 1: was performed Salkowski reaction for the determination of steroidal nucleus. going from yellow color to purple is a positive result.

Tube 2: $1.0 \mathrm{~mL}$ of Reactive Kedde. Pink or blue-violet to visible indicates cardenolide the bufadienólidos not react. The color attenuates within minutes.

Tube 3: the reaction was carried out Keller-Kiliani (glacial acetic acid in a drop III ferric chloride to $5 \%$ methanol and concentrated sulfuric acid). intense staining is positive.

Tube 4: This was the Liebermann-Burchard reaction (1.0 mL of sample / few drops of acetic acid $+3.0 \mathrm{~mL}$ acetic anhydride / sulfuric acid (50: 1, v / v) Positive Result: Coloring green, blue-green, purple blue.

Tube 5: This was the reaction Baljet $(1.0 \mathrm{~mL}$ of sample / eight drops of acetic acid $+3.0 \mathrm{~mL}$ of chloroform). Positive result: orange color, purple or red.

Tube 6: This was Raymond reaction (the extract is filtered and added 2 drops of ferric chloride solution of $10 \%+$ two drops of lead acetate to $10 \%$ ). Positive result: color ranging from yellow to purple.

Coumarins

In a test tube was placed $2.0 \mathrm{~mL}$ of the ethanolic solution, capped with filter paper soaked in $10 \%$ solution of $\mathrm{NaOH}$ and brought to a water bath at $100^{\circ} \mathrm{C}$ for some 10 minutes. It was removed and the filter paper was examined under ultraviolet light. The yellow or green fluorescence indicates the presence of coumarins.

Flavonoids

This study is based on the modification of the structure of the flavonoid in the presence of acid. Was placed in a tube, $2.0 \mathrm{~mL}$ ethanolic extract being added two drops of $10 \%$ lead acetate. The presence of a colored precipitate indicates positive aspects of the reaction

Tannins

The $2.0 \mathrm{~mL}$ of the ethanol extract was added $10 \mathrm{~mL}$ of distilled water. They were filtered and were added two drops using a Pasteur pipette, the $10 \%$ ferric chloride solution. blue color indicates possible presence of hydrolysable tannins and green staining tannins.

\section{Saponins}

In this assay, with $2.0 \mathrm{~mL}$ of ethanolic solution, was added $5.0 \mathrm{~mL}$ of boiling distilled water. After cooling, stirred vigorously, leaving at rest for 20 minutes. It is classified by the presence of saponins foaming.

Triterpenes

In this assay, with $2.0 \mathrm{~mL}$ of ethanolic solution, was added $5.0 \mathrm{~mL}$ of chloroform. After filtration, the extract was divided into two portions. In each tube there were the Liebermann-Burchard reactions and Salkowski. The triterpenes develop color and stable steroids develop color changing with time

\section{Results and Discussion}

\section{Collection and preparation of botanical struc- tures}

After processing, the botanical structures provided the following quantities fresh materials and dried materials, which demonstrated sufficient sample for ongoing research (Table 1$)$ :

Species of Celastraceae family, highlighting the gender Maytenus, has been the subject of numerous phytochemical investigations and many secondary metabolites have biological activities. The major classes of metabolites include those described pentacyclic triterpenes and friedelânicos quinonamethide, sesquiterpenes, secofriedelanos, steroids, agarofurânicos derivatives, glycosides, proanthocyanidins, flavonoids glycosides, sesquiterpene alkaloids pyridine and catechins (HURTADO, 2013).

Table 1: Botanical structures collected to yield the extract, fresh weight and dry weight

\begin{tabular}{c|c|c|c}
\hline $\begin{array}{c}\text { Plant } \\
\text { material }\end{array}$ & $\begin{array}{c}\text { Weight } \\
\text { fresh }(\mathrm{g})\end{array}$ & $\begin{array}{c}\text { Weight dry } \\
(\mathrm{g})\end{array}$ & $\begin{array}{c}\text { Extract } \\
\text { yield }(\mathrm{mL})\end{array}$ \\
\hline Leaves & $1.122,67$ & 506,15 & 50 \\
\hline Bark & $2.030,44$ & 379,16 & 75 \\
\hline Stems & 909,32 & 290,75 & 53 \\
\hline
\end{tabular}

\section{Identification of secondary metabolites of botanical structures}

The secondary metabolites found in the leaves were for alkaloids, glycosides cardiotonic using Salkowiski reagents, Keller-Killiani, Baljet and Raymond, coumarins, flavonoids, tannins, saponins and triterpenes. But results were negative for cardiotonic glycosides using reagents Kedde and Liebermann-Burchard and triterpenoids using the reagent Salkowiski, according to Table 2:

For the secondary metabolites of the stems, the results were positive for: alkaloids, cardiotonic glycosides using Salkowiski reagents, Keller-Killiani, Baljet and Raymond, coumarins, flavonoids, tannins, saponins and triterpenes. But results were negative for cardiotonic glycosides using reagents Kedde and Liebermann-Burchard, according to Table 3:

While for the secondary metabolites of bark, the results were positive for: alkaloids, cardiotonic glycosides using reagents and Salkowiski Baljet, coumarins, flavonoids, condensed tannins and triterpenes. But results were negative for cardiotonic glycosides using Kedde reagents, Keller-Killiani, Liebermann-Burchard and Raymond and saponins, according to Table 4:

Based on the results obtained, the qualitative phytochemical analysis indicated the presence of large num- 
Table 2: Identification results of secondary metabolites of ethanol extract of the leaves of M. guianensis

\begin{tabular}{|c|c|c|}
\hline Secondary metabolites & Extract ethanol & Colouring/Precipitation \\
\hline \multicolumn{3}{|l|}{ Alkaloids } \\
\hline Reagent the Mayer & Positive & Orange \\
\hline Reagent the Wagner & Positive & Cream \\
\hline Reagent the Dragendorff & Positive & Orange \\
\hline \multicolumn{3}{|l|}{ Glycosides cardiotonic } \\
\hline Reagent the Salkowiski & Positive & Red \\
\hline Reagent the Kedde & Negative & Yellow \\
\hline Reagent the Keller-Killiani & Positive & Dark green \\
\hline $\begin{array}{c}\text { Reagent the Liebermann } \\
\text { Burchard }\end{array}$ & Negative & Yellow \\
\hline Reagent the Baljet & Positive & Orange \\
\hline Reagent the Raymond & Positive & Orange \\
\hline Coumarins & Positive & Green fluorescence \\
\hline Flavonoids & Positive & Red \\
\hline Tannins & Positive & Green \\
\hline Saponins & Positive & Foaming \\
\hline \multicolumn{3}{|l|}{ Triterpenes } \\
\hline $\begin{array}{c}\text { Reagent the Liebermann- } \\
\text { Buchard }\end{array}$ & Positive & Brown \\
\hline Reagent the Salkowski & Negative & Red \\
\hline
\end{tabular}

ber of classes of secondary metabolites present in the leaves, stems and bark of M. guianensis. Of secondary metabolites analyzed the substances that were found present alkaloids, coumarins, flavonoids and tannins using all specific reagents. The absence of other compounds may be associated with the degree of ripeness at harvest, by genetic differences between cultivars, storage conditions, time between harvesting and pulping and storage conditions of the pulp, among other factors, as expressed Schmidt (2009).

Still According Bobbio; Bobbio (2003), the degradation of some compounds may occur during the extraction of vegetable, processing and storage of food, influenced by extrinsic and intrinsic factors. Temporal and spatial variations in total content as well as the relative proportions of secondary metabolites in plants occur at different levels (seasonal and daily; intraplanta, interand intraspecific), and despite the existence of a genetic control, the expression may undergo modifications resulting from interaction of biochemical, physiological, ecological and evolutionary processes. They represent a chemical interface between the plant and the surrounding environment, so its synthesis is often affected by environmental conditions (COUTINHO, 2013).
The plant extracts containing alkaloids are used as medicines, poisons and magic portions since the dawn of civilization. Thus it is difficult to establish the correct origin of the discovery of these substances. Records indicate that opium was used by the Sumerians 4000 years BC because of its soporific and analgesic properties (HOSTETTMAN et al., 2003).

The isolation of the first pure substances from the plant kingdom begins to happen in the nineteenth century. This century characterized by extracting work mainly organic acids and organic bases which later received alkaloids denomination. Are this time the isolation of morphine (1804), quinine and strychnine (1820) (ALMEIDA et al., 2009).

Currently, numerous experiments show the fact that many secondary metabolites present in plants, such as terpenes, alkaloids, cyanogenic glycosides, saponins, tannins, anthraquinones are allelochemicals representing adaptive characters and has diversified during evolution by natural section to protect plants against viruses, bacteria, fungi, plants and competing against herbivores (WINK, 2003).

Cardiac glycosides are complex triterpene molecules created by amphibians and plants that exert intense biolo- 
Table 3: Identification results of secondary metabolites of ethanol extract of the stems of M. guianensis

\begin{tabular}{|c|c|c|}
\hline Secondary metabolites & Extract ethanol & Colouring/Precipitation \\
\hline \multicolumn{3}{|l|}{ Alkaloids } \\
\hline Reagent the Mayer & Positive & Orange \\
\hline Reagent the Wagner & Positive & Purple \\
\hline Reagent the Dragendorff & Positive & Orange \\
\hline \multicolumn{3}{|l|}{ Glycosides cardiotonic } \\
\hline Reagent the Salkowiski & Positive & Red \\
\hline Reagent the Kedde & Negative & Orange \\
\hline Reagent the Keller-Killiani & Positive & Dark green \\
\hline $\begin{array}{c}\text { Reagent the Liebermann } \\
\text { Burchard }\end{array}$ & Negative & Yellow \\
\hline Reagent the Baljet & Positive & Orange \\
\hline Reagent the Raymond & Positive & Orange \\
\hline Coumarins & Positive & Green fluorescence \\
\hline Flavonoids & Positive & Red \\
\hline Tannins & Positive & Gren \\
\hline Saponins & Positive & Foaming \\
\hline \multicolumn{3}{|l|}{ Triterpenes } \\
\hline $\begin{array}{c}\text { Reagent the Liebermann- } \\
\text { Buchard }\end{array}$ & Positive & Brown \\
\hline Reagent the Salkowski & Positive & Orange \\
\hline
\end{tabular}

gical effects in humans and many other organisms. While extremely toxic, these molecules often have therapeutic use, when properly administered in minute quantities. In humans, small amounts of cardiac glycosides soften and strengthen the heart beat. They do this by blocking the sodium and potassium pump of heart cells, which leads to a delay in the electrical signal between the atria and the ventricles. In larger amounts, cardiac glycosides can be extremely toxic, rapidly induce drowsiness, color vision disorders, slow and irregular heart rhythm, followed by death (SIMÕES et al., 2004).

The coumarin found in all botanical structures $M$. guianensis are a chemical class, the first isolated representative of Vogel in 1820, the species coumarone odorata. These metabolites are present in different parts of the plants both in the roots and in the flowers and fruits and may be distributed in different families of Angiospermae as Apiaceae, Rutaceae, Asteraceae in which are found with wide occurrence. Also present in Fabaceae, Oleaceae, Moraceae and Thymeleaceae. Among the taxa that biosynthesize coumarins have species of very diverse habits, such as trees, shrubs and herbs (RIBEIRO; KAPLAN, 2002).

The plants rich in alkaloids pyrrolizidine began to be studied by chemists of natural products because farmers in many parts of the world, began to associate them with the intoxication of ruminants and horses, which caused serious economic problems (BULL et al., 1968).

Flavonoids also found in all botanical structures $M$. guianensis represent one of the major phenolic groups and diverse among the products of natural origin. This class of secondary metabolites is widely distributed in the plant kingdom (SIMÕES et al., 2004). They are found in fruits, vegetables, seeds, bark, roots, stems, flowers and their preparation products such as tea and wine (NIJVELDT et al., 2001). They have a characteristic core C6 -C3 -C6 being biosynthesized from the channels of shikimic acid and acetic acid (CAZAROLLI et al., 2002).

Clinical studies have been conducted in various parts of the world in order to verify the effectiveness of flavonoids in diseases of inflammatory origin, such as interstitial lung disease, idiopathic pulmonary fibrosis, asthma and pulmonary sarcoidosis. In these studies highlight the flavonol quercetin. Moreover, efficacy studies involving synthetic derivatives are also being developed (HOWES et al., 2007).

The pentacyclic triterpenes and friedelânicos quinonamethide are the most common in plant extracts of $\mathrm{M}$. guianensis (HURTADO, 2013). The reported biological structures and functions are: pentacyclic triterpenes: a skeleton is formed by three carbon atoms may be arranged in five six-membered rings (NUÑEZ et al., 
Table 4: Identification results of secondary metabolites of ethanol extract of bark of M. guianensis

\begin{tabular}{|c|c|c|}
\hline Secondary metabolites & Extract ethanol & Colouring/Precipitation \\
\hline \multicolumn{3}{|l|}{ Alkaloids } \\
\hline Reagent the Mayer & Positive & Orange \\
\hline Reagent the Wagner & Positive & Purple \\
\hline Reagent the Dragendorff & Positive & Orange \\
\hline \multicolumn{3}{|l|}{ Glycosides cardiotonic } \\
\hline Reagent the Salkowiski & Positive & Green \\
\hline Reagent the Kedde & Negative & Orange \\
\hline Reagent the Keller-Killiani & Negative & Yellow \\
\hline $\begin{array}{c}\text { Reagent the Liebermann } \\
\text { Burchard } \\
\end{array}$ & Negative & Yellow \\
\hline Reagent the Baljet & Positive & Orange \\
\hline Reagent the Raymond & Negative & Red \\
\hline Coumarins & Negative & Not Green fluorescence \\
\hline Flavonoids & Positive & Orange \\
\hline Tannins & Positive & Green \\
\hline Saponins & Negative & No foaming \\
\hline \multicolumn{3}{|l|}{ Triterpenes } \\
\hline $\begin{array}{l}\text { Reagent the Liebermann- } \\
\text { Buchard }\end{array}$ & Positive & Brown \\
\hline Reagent the Salkowski & Positive & Red \\
\hline
\end{tabular}

2005). The populnônico acid, isolated from the bark of Austroplenchia populnea, has anti-inflammatory activity. This plant is found in the Brazilian Cerrado and used in folk medicine for the treatment of dysentery and inflammations such as rheumatism (ANDRADE et al., 2007); Sesquiterpenes: Basic skeleton dihydro- $\beta$ -agarofurano. This structure comprises rings $\mathrm{A}$ and $\mathrm{B}$ as a decalin, having a melt tetrahydrofuranyl bridge. This isolated from Celastrus vulcanicola presents photosynthetic inhibition activity. The isolated constituents of this plant and its biological activity had not yet been investigated. C. vulcanicola is a subtropical woody vine distributed in Central America and the Caribbean (TORRES-ROMERO et al., 2008); Quinonamethide triterpenes: secondary metabolites are restricted to higher plants of Celastraceae family (CORSINO et al., 2000). Tingenone is a substance isolated from the roots of several species of the family Celastraceae, for example, Austroplenckia populnea (DUARTE et al., 2006) and Hippocratea excelsa (MENA-REJÓN et al., 2007). Has numerous biological activities, such as Trypanosoma cruzi (DUARTE et al., 2006), intestinal Giardia (MENA-REJON et al., 2007) and inhibition of tubulin protein that may be the mode of action which justifies the cytotoxic and antitumor activity (MORITA et al., 2008).

Steroids or triterpenes constitute the essential or volatile oils. According Fracaro et al. (2004), there is no fundamental difference between the triterpenes and sterols, considering the latter as tetracyclic triterpenes have lost at least three methyls. These metabolites are found in the ethanol extracts of bark and stems of medicinal plants, because their therapeutic interest gives to the importance of cardiotonic glycosides, which are part of this group. Tannins have proved positive in this study, can be used to treat diarrhea, as diuretics in stomach problems (heartburn, gastritis, gastric ulcer, tumor stomach and duodenum) and also as anti-inflammatory, antiseptic and haemostatic (CUNHA et al., 2010).

The presence of saponins was confirmed in the study with only the leaves and bark, as to be busy, the plant extract formed foams, indicating a positive result. According Yang et al. (2010), the antifungal activity of saponins, is due to the interaction of these sterols with the plasma membrane

\section{Conclusion}

From the experiments, it was found that all botanical structures fitoquimicamente tested exhibit secondary metabolites (alkaloids, coumarins, flavonoids, tannins and triterpenes). However, it is necessary that this species 
is subject to phytochemicals biomonitorados studies, in order to isolate and identify the active compounds and establish relationship with the biological activities observed in popular use.

\section{Acknowledgements}

The authors thank the National Council for Scientific and Technological Development (CNPq) for financial support and the Research Support Foundation of Amazonas State (FAPEAM) for granting the scholarship for the first author.

\section{References}

ALHO, C.J.R. Importância da biodiversidade para a saúde humana: uma perspectiva ecológica. Estudos avançados, v.26, n.74, p.156-164, 2012.

ALMEIDA, M.R.; LIMA, J.A.; SANTOS, N.P.; PINTO, A.C. Pereirina: o primeiro alcaloide isolado no Brasil? Revista Brasileira de Farmacognosia, v.19, n.4, p.54-60, 2009.

ANDRADE, S.F.; CARDOSO, L.G.V.; CARVALHO, J.C.T.; BASTOS, J.K. Anti-inflammatory and antinociceptive activities of extract, fractions and populnoic acid from bark wood of Austroplenckia populnea. Journal of Ethnopharmacology, v.109, p.464-471, 2007.

ANDRADE, J.I.A. Atividade antibacteriana dos extratos dos frutos de Coussapoa asperifolia magnifolia (Trécul) contra Aeromonas hydrophila e fracionamento do extrato metanólico. 2009. Dissertação (Mestrado em Biotecnologia) - Universidade Estadual do Amazonas, Manaus.

BOBBIO, F.O.; BOBBIO, P.A. Introdução à Química dos Alimentos. 3ed. São Paulo: Varela, 2003.

BORRÁS, M.R.L. Plantas da Amazônia: medicinais ou mágicas - Plantas comercializadas no Mercado Municipal Adolpho Lisboa. Manaus: Valer, 2003. 322p.

BUlL, L.B.; CUlVENOR, C.C.; DICK, A.J. The Pyrrolizidine Alkaloids: Their Chemistry, Pathogenicity and Other Biological Properties. Amsterdam: NorthHolland, 1968.

CAZAROLLI, L.H.; ZANATTA, L.; ALBERTON, E.H.; FIGUEIREDO, M.S.R.B. Mini-Revisão sobre metabólitos secundários. Medicinal Chemical, v.8, n.1, p.1429, 2002.

CORSINO, J.; CARVALHO, P.R.F.; KATO, M.J.; LATORRE, L.R.; OLIVEIRA, O.M.M.F.; ARAÚJO, A.R.; BOLZANI,
V.S.; FRANÇA, S.C.; PEREIRA, A.M.S.; FURLAN, $\mathrm{M}$. Biosynthesis of friedelane and quinonemethide triterpenoids is compartmentalized in Maytenus aquifolium and Salacia campestres. Phytochemistry, v.55, p.741-748, 2000.

COUTINHO, M.R. Extração de tanino em folhas, sementes e frutos verdes de cinamomo (Melia azedarach L.) com diferentes tipos de solventes. 2013. 42f. Trabalho de conclusão de curso de graduação: Tecnologia em Alimentos da Coordenação dos Cursos de Tecnologia e Engenharia de Alimentos, da Universidade Tecnológica Federal do Paraná - UTFPR. 42f.

CUNHA, A.P.; SALGUEIRO, L.; ROQUE, O.R. Metilxantinas. In: CUNHA, A. P. (Org). Farmacognosia e Fitoquímica. 3. ed. Lisboa: Fundação Calouste Gulbenkian, 2010.

DAS, B. K.; SAHU, S.; PRADHAN, J.; MOHAPATRA, B.C.; MISHRA, B.K.; SARANGI, N. Effect of Magnifera indica kernel as a feed additive on immunity and resistance to Aeromonas hydrophila in Labeo rohita fingerlings. Fish \& Shellfish Immunology, v.23, p.109-118, 2007.

DUARTE, L.P.; VIEIRA-FILHO, S.A.; SILVA, G.D.F.; SOUSA, J.R.; PINTO, A.S. Anti-trypanosomal activity of pentacyclic triterpenes isolated from Austroplenckia populnea (Celastraceae). Revista do Instituto de Medicina Tropical de São Paulo, v.44, n.1, p.109-112, 2006.

DUKE, J.A.; VÁSQUEZ, R. Amazonian ethnobotanical dictionary. CRC Press, Boca Raton, Florida, USA, 1994. $114 \mathrm{p}$.

FONSECA, A.P.N.D.; SILVA, G.D.F.; CARVALHO, J.J.; SALAZAR, G.D.C.M.; DUARTE, L.P.; SILVA, R.P.; TAGLIATI, C.A.; ZANI, C.L.; NEVES, T.M.A.; PERES, V.; VIEIRA-FILHO, S.A. (2007). Estudo fitoquímico do decocto das folhas de Maytenus truncata Reissek e avaliação das atividades antinociceptiva, antiedematogênica e antiulcerogênica de extratos do decocto. Química Nova, v.30, n.4, p.842-847.

FRACARO, S.N.; DECONTO, I.; NAKASHIMA, T. Potencial de toxicidade reprodutiva do extrato de Tillandsia usneoides Linnaeus, 1762 (barba-de-pau) em coelhas gestantes. Tese (Mestrado em Ciências Veterinárias), Universidade Federal do Paraná. Curitiba, 2004, 60p.

GONÇALVES, A. L.; ALVES-FILHO, A.; MENEZES, H. Estudo comparativo da atividade antimicrobiana de extratos de algumas árvores nativas. Arquivos do Instituto Biológico, v.72, n.3, p.353-358, 2005. 
HOSTETTMAN, K.; QUEIROZ, E.F.; VIEIRA, P.C. Princípios ativos de plantas superiores. São Carlos: EdUFSCar. 2003.

HOWES, L.G.; JAMES, M.J.; FLORIN, T.; WALKER, C. Expert Opin. Invest. Drugs v.16, n.1, p.1255, 2007.

HURTADO, F.B. Contribuição ao estudo fitoquímico e biológico da entrecasca da espécie Maytenus guianensis Klotzsch ex Reissek. 2013. 170 f. Doutorado em Biologia Experimental. Universidade Federal de Rondônia, Porto Velho.

MACARI, P.A.T.; PORTELA, C.N.; POHLIT, A.M. Antioxidant, cytotoxic and UVB-absorbing activity of Maytenus guianesis Klotzsch (Celastraceae) bark extracts. Acta Amazônica, v.36, n.4, p.513-518, 2006.

MATOS, F.J. Introdução à fitoquímica experimental. 3.ed. Fortaleza: Edições UFC, 2009. 141p.

MENA-REJÓN, G.J.; PÉREZ-ESPADAS, A.R.; MOOPUC, R.E.; CEDILLO-RIVERA, R.; BAZZOCCHI, I.L.; JIMÉNEZ-DIAZ, I.A.; QUIJANO, L. Antigiardial activity of triterpenoids from root bark of Hippocratea excelsa. Journal of Natural Products, v.70, p.863-865, 2007.

MICHELIN, D.C.; MORESCHI, P.E.; LIMA, A.C.; NASCIMENTO, G.G.F.; PAGANELLI, M.O.; CHAUD, M.V. Avaliação da atividade antimicrobiana de extratos vegetais. Revista Brasileira de Farmacognosia, v.15, n.4, p.316-320, 2005.

MORITA, H.; HIRASAWA, Y.; MUTO, A.; YOSHIDA, T.; SEKITAB, S.; SHIROTAB, O. Antimitotic quinoid triterpenes from Maytenus chuchuhuasca. Bioorganic Medicinal Chemistry Letters, v.18, p.1050-1052, 2008.

NIJVELDT, R.J.; NOOD, E.; HOORN, D.E.C.; BOELENS, P.G.; NORREN, K.; LEEUWEN, P.A.M. Flavonoids: a review of probable mechanisms of action and potential applications. Am. J. Clin. Nutr., v.74, n.1, p.418, 2001.

NUÑEZ, M.J.; REYES, C.P.; JIMÉNEZ, I.A.; MOUJIR, L.; BAZZOCCHI, I.L. Lupane triterpenoids from Maytenus species. Journal of Natural Products, v.68, n.7, p.10181021, 2005.

OLIVEIRA, D.M.; SILVA, G.D.F.; DUARTE, L.P.; VIEIRA, S.A. Chemical constituents isolated from roots of Maytenus acantophylla Reissek, Celastraceae. Biochemical Systemy Ecology, v.34, p.661-665, 2006.

REVILLA, J. Apontamentos para a cosmética Amazônica. SEBRAE-INPA, Manaus, Amazonas, 2002. 445p.
RIBEIRO, C.V.C.; KAPLAN, M.A.C. Tendências evolutivas de famílias produtoras de cumarinas em Angiospermae. Química Nova, v.25, n.4, p.533-538, 2002.

SCHIMIDT, D. Palmeira Juçara: exploração ecológica dos frutos. Agroecologia e Saúde, 2009.

SIMÕES, C.M.O.; SCHENKEL, E.P.; GOSMANN, G.; MELLO, J.C.P.; MENTZ, L.A.; PETROVICK, P.R. Farmacognosia: da Planta ao Medicamento, 5.ed. Editora da UFSC: Santa Catarina, 2004.

TANAKA, J.C.A.; SILVA, C.C.; FILHO, B.P.D.; NAKAMURA, C.V.; CARVALHO, J.E.; FOGLIO, M.A. Constituintes químicos de Luehea divaricata Mart. (Tiliaceae). Química Nova, v.28, n.5, p.834-837, 2005.

TORRES-ROMERO, D.; KING-DIAZ, B.; JIMÉNEZ, I.A.; LOTINA-HENNSEN, B.; BAZZOCCHI, I.L. Sesquiterpenes from Celastrus vulcanicola as photosynthetic inhibitors. Journal of Natural Products, v.71, p.1331-1335, 2008.

YANG, C. R. et al. Antifungal activity of C-27 steroidal saponins. Antimicrobial agents and chesmotherapy. .50 (5). p. 1710-1714, 2006.

WINK, M. Evolution of secondary metabolites from anecological and molecular phylo genetic perpective. Phytichemistry, v.64, n.1, p.3-19, 2003.

ZILBERG, D.; ABUTBUL, S.; GOLAN-GOLDHIRSH, A.; BARAZANI, O. Use of Rosmarinus officinalis as a treatment against Streptococcus iniae in tilapia (Oreochromis sp.). Aquaculture, v.238, p.97-105, 2004. 